\title{
Criminal Liability against a Doctor Who Does Not Have a License Practices in Providing Health Services
}

\author{
Redyanto Sidi ${ }^{1}$, Kharmaedisyah Putra ${ }^{2}$, Mirza Kesuma ${ }^{3}$, \\ Rodeo Valentino Siahaan ${ }^{4}$ \\ ${ }^{1}$ Lecturer Master of Laws Postgraduate Universitas Pembangunan Panca Budi \\ ${ }^{2,3,4}$ Students of the Master of Laws Postgraduate Universitas Pembangunan Panca Budi \\ Corresponding Author: Redyanto Sidi
}

\section{ABSTRACT}

Doctors and medical personnel who perform the activities of the medical service must have permission practices of the country in accordance with applicable regulations, and the provision of medical services must be in accordance with the authority of the medical profession. Doctors who perform the activities of health services must have a Letter of Permission Practices of the government in accordance with the regulations in force, in the conduct of health services should be based on the competency of medicine. If in providing health deviate from the rules that have been specified then it will get penalized in accordance with the applicable legislation. This research using the method of normative legal research that is done by researching secondary data collected with the approach of the study of literature to study secondary data associated with the service issues the practice of medicine. Secondary Data in this research consists of primary and secondary legal materials are compiled systematically and analyzed qualitatively. The results of this research show that the Forms of criminal acts in the health services is a criminal offence which is regulated in the criminal code as well as regulated in the Law Practice of Medicine. Health services provided to patients without registration letter doctor is one of the forms of criminal acts that is set in the Law Practice of Medicine. Someone who is committing a crime, including criminal acts in the service of health must account for his actions. Its criminal a person must be proven about the crime that he did. Ability is
\end{abstract}

responsible for an element of error, then to prove the existence of a fault element of the last to be proven again.

Keywords: Criminal Liability, Health Services, A Letter Of Permission Physician Practice

\section{INTRODUCTION}

The law is generally defined as a set of rules-perarutan written in a community as a guide in the society in order not to create a crime and violation of public order. The law aims to provide legal protection to every member of society, then objectively it also means that the medical profession must also be protected rights when providing health services by the law. In addition to doctors, the patient who is also a member of the community necessarily require the provisions of the law that can protect the patient from the medical doctor in accordance with the rules of applicable law. In this situation the law is needed to set up so the doctors obey the rules that have been set by profession doctor.

Public awareness of the rights which continue to increase in the era of globalization is one positive indicator for increasing awareness of the law in society. However, on the other hand more and more doctors or hospitals in the manner complained of and/or disomasi even sued by the patient so that the influence doctors in the health service. 
Error when working or referred to as a breach of discipline which is caused due to negligence during practice and the work is already common in every type of job such as a doctor, midwife, medical. The error is called with the human error of Liability as to the error must first pay attention to the evidence and the cause before granting sanction.

Health as part of human rights should be realized in the form of various efforts of health care services to each member of the community through the implementation of health development quality and affordable for the community, the organization of medical practice that is at the core of a variety of health services to be performed by doctors and dentists who have ethics and morals high. The profession of the doctor and the dentist should be improved quality through education and ongoing training, certification, registration, licence coaching, supervision, and monitoring for the implementation of medical practice in accordance with the development of science and technology. To provide protection and legal certainty to patient as the recipients of health services and health workers needed the rule of law on the implementation of the practice of medicine.

Doctors who perform the activities of health services must have a Letter of Permission Practices of the government in accordance with the regulations in force, in the conduct of health services should be based on the competence of the medicine. If in providing health deviate from the rules that have been specified then it will get penalized in accordance with the applicable legislation.2 Consequences to the doctor or dentist that intentionally engage in the practice of medicine without having a practice license can be punished with imprisonment and a fine as provided for in the Legislation of the Republic of Indonesia Number 29 Year 2004 on Medical Practice. Certificate of registration of the doctor and the dentist is written evidence given by the
Medical Council of Indonesia to the doctor and dentist has been registered.

One example is the case of the practice of medicine that make health services without having permission practices is conducted by Suharto, A. Md.RO., A. Md.Kep., SKM who is a nurse at the Puskesmas District Singkawang Tengah Singkawang City based on the Letter Designation Number 800/48/TU 02 January 2014 as the coordinator of the health of the senses of the eye that has received delegation of authority letter from the health center Doctor to perform services examination and treatment of the eye in patients.

Suharto, A. Md.RO., A. Md.Kep., SKM not explain in advance to the patient (victim), Yenny Hestiaty aka Yeny bin Mahmud Hanipah about tools, methods or manner as do the actions and then the patient is asked to sit in a chair special care of the eyes and observation where Suharto, A. Md.RO., A. Md.Kep., SKM say there is a foreign object on the part of the eyeball or the peak of the cornea of the patient so that the impression that the Suharto, A. Md.RO., A. Md.Kep., SKM is doctors eye specialists who have specialist expertise in the field of the eye. Then Suharto A. Md.RO., A. Md.Kep., SKM directly shed drops as much as approximately 1 (one) drop of and pick up foreign objects referred to by using a tool such as the form of needles or soft like a stick, but not hard yet pliable colored chocolate and perform irrigation to the patient's eye with the use of water, take a foreign body in the cornea of patients with how to shift a tool used Suharto A. Md.RO., A. Md.Kep., SKM such or was placed to the ball of the left eye of the patient without preceded by and or approval of the medical action of the patient (informed consent patient), then Suharto A. Md.RO., A. Md.Kep., SKM give eye drops to a patient where the patient feels his eyes sick and was asking about it but got the answer that it is the reaction of the drug has been given. 


\section{MATERIAL AND METHOD}

This research using the method of normative legal research that is done by researching secondary data collected with the approach of the study of literature to study secondary data associated with the the problem of the service the practice of medicine. secondary Data in this research consists of primary and secondary legal materials are compiled systematically and analyzed qualitatively.

\section{RESULTS AND DISCUSSION Forms Of Criminal Acts In Health Services}

Health care is an effort to keep the health, cure disease and restore the health of the person, the family and the community where its implementation can be done independently or together through an organization. Five Doctors and nurses in the provision of health services by the hospital, are health professionals who hold an important role. Doctor authorized to perform medical procedures based on medical science, while the nurse is a person who is trained to be a paramedical personnel to organize the care of patients or in particular to explore the field of a particular treatment, such as anesthesiologists and expert care space emergency room.

Certain medical is performed by a doctor aims to cure the patient is done by way of treatment or surgery, while nursing actions aimed at improving or maintaining optimal health of the patient. Nurses in carrying out their duties must be always under the supervision of a physician, because in nursing practice there are functions dependent, where in this function of the nurse acts to help doctors in providing medical services. The nurse helps the doctor to provide services in terms of treatment and specific actions which become the authority of doctors and should be done by a doctor, such as infusion, administration of the drug and do the injections so that any failure of medical action be the responsibility of the doctor. Every action of the nurse under doctor's orders to not ignore the rights of the patient, not included in the responsibilities of the nurse.

Some of the medical services provided by the hospital resulted in some medical errors and/or malpractice due to the fault or negligence of the health officer. As a subordinate to the physician treating the patient, the nurse usually fail in diagnosing the patient and wrong in determining the dose of the drug, resulting in errors and omissions. Some injured patients who reported an event that suffered because of the negligence of a nurse, although some patients report not go to court because of the wide selection of peace offered by the hospital.

The government as the organizer of the state issued several regulations to regulate the subject of health, the organization of the hospital as well as the practice of medicine, and included in it the relationship between the doctor and the patient, namely Law Number 29 Year 2004 About the Practice of Medicine, Law Number 36 Year 2009 On Health, as well as Legislation- Act No. 44 of 2009 About the Hospital, as well as the Law Number 8 Year 1999 Concerning Consumer Protection provides the basis for the patient to ask the efforts of the law, Ministerial Regulation No. 585/Menkes/Per/IX/1989 on the Approval of the Medical Acts, Ministerial Regulation No. 512/Menkes/Per/IV/2007 tentang Permission Practices and the Implementation of Medical Practice, Ministerial Regulation No. 269/Menkes/Per/III/2008 of the Medical Record provide technical arrangements for the patient and the doctor when incurred losses in medical services.

Malpractice criminal occur if the patient died or become disabled because of the negligence or carelessness of medical personnel in caring for patients who died or defects. Malpractice in the criminal law can be found in the Book of the Law of Criminal Law, namely: 1) fool the patient (Article 378 of the criminal code); 2) create the false certificate (Article 263 and 267 of the criminal code); 3) do the negligence 
resulting in the death of atau wound (Article $359, \quad 360$ and 361 of the criminal code);4)violation of decency (Article 290, paragraph (1), 294, paragraph (2), 285, and 286 of the criminal code) 5) do the abortion without medical indications (Article 299, $348,349,350$ of the criminal code) 6) to divulge the secret medicine that complained of by the patient (Article 322 of the criminal code); does not give aid to people who are in a state of mortal danger (Article 361 of the criminal code); to give or sell counterfeit drugs (Article 386 of the criminal code); and Euthanasia (Article 344 of the criminal code).

Specifically, regarding the issue resulted in the death of people or injured because of the fault (Article 359, 360 and 361 of the criminal code) in the science of criminal law, the error can be caused due to deliberate (opzet) or gross negligence/negligence (culva). However, in this case in connection with the problem of malpractice, the error is in the sense of negligence/negligence. So do not deliberate before such as in the case of persecution. Meanwhile, according to the Legislation of the Republic of Indonesia Number 29 Year 2004 on Medical Practice of action that can be punished among other things:

a. Practicing medicine without a certificate of the Register (Article 75 paragraph (1));

b. Practices medicine without having the Permit Practice (Article 76)

c. Using the identity in the form of a degree or other shapes that create the impression for the public as if he was the doctor or the dentist (Article 78);

d. Do not attach the nameplate (Article 79 letters a);

e. Make no medical record (Article 79 letters b);

f. Does not meet the obligations in accordance with the provisions of Article 51 (Article 79 letters c);

g. Corporate or individual that employs a doctor or dentist without have registration letter and permit practice (Article 80)
Based on Article 76 of Law No. 29 of 2004 on Medical Practice determine that the consequences for the doctor or dentist who deliberately engage in the practice of medicine without having a license practices shall be punished by a maximum imprisonment of 3 (three) years and/or a fine of at most Rp. 100.000.000,00 (serratus million dollars).

With respect to the people who use identity in the form of a degree or other shapes that create the impression for the public as if he was the doctor or dentist Article 73 paragraph (3) of Law Number 29 Year 2004 on Medical Practice states that every person who use identity, device, or method in providing health services as if the impression as a physician or dentist does not apply to health personnel authorized by the laws and regulations.

So based on Article 73 of the people who provide services to the community that gave the impression as if he was the doctor or dentist that has a certificate of registration a doctor or a registration letter dentist or practice license as specified in Article 78 of Law Practice of Medicine is a public person that behave and do as if he was the doctor or the dentist like the quack doctor so not for health workers called the nursing personnel.

Thus the case of the nurse Suharto, A. Md.RO., A. Md.Kep., SKM that do medical treatment to patients that have been described in the background above is based on the provisions of Article 73 and Article 78 of the Law of Medical Practice does not include medical services rendered to the community that gave the impression as if he was the doctor or dentist that has a certificate of registration a doctor or a registration letter dentist or permit practice because Suharto,A.Md.RO., A. Md.Kep., SKM has been given the authority of Puskesmas District Singkawang Tengah Singkawang City based on the Letter Designation Number 800/48/TU date January 02, 2014 and Suharto, A. Md.RO., A. Md.Kep., SKM is not a public person that acts as a quack doctor. 
Based on the description above, the forms of criminal acts in the health services is a criminal offence which is regulated in the criminal code which consists of 1 ) fool the patient (Article 378 of the criminal code); 2) create the false certificate (Article 263 and 267 of the criminal code); 3) perform the negligence resulting in the death of or injuries (Article 359, 360 and 361 of the criminal code); 4) violation of decency (Article 290, paragraph (1), 294, paragraph (2), 285,dan286 of the criminal code) 5) do pengguran without medical indications (Article 299, 348, 349, 350 KUHP); 6) to divulge the secret medicine that complained of by the patient (Article 322 of the criminal code); do not give aid to people who are in a state of mortal danger (Article 361 of the criminal code); to give or sell counterfeit drugs (Article 386 of the criminal code); and Euthanasia (Article 344 of the criminal code). In addition to the provisions in the criminal code also stipulated in the Law Practice of Medicine ie:

a. Practicing medicine without a certificate of the Register (Article 75 paragraph (1));

b. Practices medicine without having the Permit Practice (Article 76)

c. Using the identity in the form of a degree or other shapes that create the impression for the public as if he was the doctor or the dentist (Article 78);

d. Do not attach the nameplate (Article 79 letters a);

e. Make no medical record (Article 79 letters b);

f. Does not meet the obligations in accordance with the provisions of Article 51 (Article 79 letters c);

g. Corporate or individual that employs a doctor or dentist without have registration letter and permit practice (Article 80).

\section{Criminal Liability For The Actions Of Health Services Given By The Doctor Without License Practices In Providing Health Services}

In criminal law, criminal responsibility is a concept that is known as the principle of error. Errors in the narrow sense can be either intentional (opzet) or carelessness (culpa). In Latin, the doctrine of mistake is called the mens rea. The doctrine of the human based on the actions that do not lead to the convictions of man unless mind is evil. Criminal responsibility is an assessment of whether a suspect or defendant can be held liable for a criminal act. Seven

Criminal responsibility is defined as the prosecution of responsibility responsible objective there in the offense and the responsibility of the subjective from the those who meet the requirements to be punished for his actions. The basis of the presence of evil is the principle of legitimacy, and the basis for the guilty to be punished is a principle of error. That is, the perpetrator of the crime will only be punishable if the perpetrator is guilty of such a crime.

The basis of the presence of a criminal act is the principle of legality and the basis for the guilty person to be punished is a principle of error. That is, the perpetrator of the crime only will be punished if he guilty of the crime for a person, the judge shall investigate it and if after dislike still there is any doubt, then the judge must free from the demands of the law.

In terms of the occurrence of an act which is prohibited, someone will be held responsible for the act, if the act was against the law and there is no justification or omissions that are contrary to law for the offense. From the standpoint of the ability to be held accountable, only people with the ability that can be held accountable for his actions. A criminal act if there is no violation is the basis of criminal responsibility, then the conviction of people who do such things have been threatened, 
depending on whether in doing the acts that he has the error.

Until now the adherents of the principle of no criminal without error still very much and it can not be separated from the influence of the flow seems contrary to the about the offense may be said to be very influential on the criminal legal system in the world. The flow seems contrary to the do not distinguish between the elements of the act with the elements of accountability. Therefore, according to the influence of the flow seems contrary to the that strafbaar feit is the same with the terms of the imposition of criminal, so that each offense then his actions dapatdipidana.Ten

Criminal liability can only be done against the person who committed the criminal act. The error is a very important thing to remove someone. Without that criminal liability will not ever, then in the criminal law known principle of no criminal without error (geen straf zonder schuld).

Based on the then criminal liability has the characteristics as following: 1) can be accounted for by the perpetrator; 2) the presence of a psychic bond between the actors and actions that the absence of accident or mistake in the sense of (culpa); 3) the absence of basic negation criminal removes the ability accounted for an act to the offender.12 a Person can't be wrong without breaking the law. To talk about a crime committed by a person, need to know whether the perpetrators can be held accountable for criminal acts that he had done.

It is not enough to punish a person if he has committed an act against the law or against the law, so that although his actions are a crime of unauthorized and unwarranted, it does not lead to punishment. Punishment always requires that the person doing the act is guilty or innocent. Based on the principle cannot be accounted for in the criminal without errors, the manufacturer can be held accountable if there are errors. Responsible is the error conditions, so it is not a part of the error itself. it Can be said that there is an error if the makers can be held accountable for his actions and deeds can dicelakan him. This reproach is not the reproach ethical but the reproach of the law. Some deeds are justified ethically can be punished.

A person may be found guilty and accountable criminal act that can be punished if it meets the elements of error in the broadest sense, as well as the subjective element. Terms of punishment subjective these include the deliberate action and gross negligence.

Intentional according to the level of deliberate consists of three kinds, namely intent as intent, deliberateness as certainty about the deeds recognized as must lead to a result and deliberate as a certainty that an act against the possibility of the emergence of a result of a deed. Intent as the intent amenable understandable by the public, so if deliberate as it's in an offense, no one can deny that the culprit should be punished. This is more apparent if it is affirmed that for the purposes of the aim can be said that the actors really want to achieve an outcome that be the main cause of criminal threats. 14 the subjective Element of the negligence (culpa), the criminal code is only a little is required for a criminal offense and is almost always mentioned once in the article that preceded it mentioned intent in a criminal the same.

Then the criminal is able to be responsible is it for the soul of a are required in it to drop the criminal and not the case for the occurrence of the criminal offense. So, for the occurrence of criminal acts need not be questioned about whether the ability of responsible or not able to be responsible. The occurrence of the criminal offense is not necessarily followed by a criminal to act, but when connecting the said act to the person to drop the criminal, if there is any doubt concerning the soul of man, then noticed or questioned about the inability of the are the answers and must also be attested to not in its criminal against the maker.

Ability is responsible for can be interpreted as a condition of the inner 
normal or healthy and have a sense of a person in discriminate the good things and the bad. Criminal liability requires the condition that the maker is able to be responsible, because it is impossible for someone can be accounted for if he is not able to be responsible. ability is responsible for is a psychological state, which justifies the application of an attempt of punishment, both in the view from the corner of the public or the person. Someone capable of responsible must meet three conditions, namely: 1) the State of mind of a person is a (normal) as far as he's free or being able to determine his desire for the behavior to be performed; 2) the State of someone's mind in such a way that he is competent enough to understand the value of his actions and their consequences; 3) the State of the soul of that person in such a way that it is able to realize, deeply realizing that the actions that will be done it is a behavior which is reprehensible, that behavior is not justified by law or by the society and the ethics. Fifteen

Circumstances that may be a reason not to give account that the maker for his actions/ability is responsible for such as: 1 ) When the maker does not have the freedom to choose between doing and not doing what is prohibited or enjoined by law;2). If the maker is in a state in such a way that he not be able to realize that his actions are illegal and can not determine the consequences of his actions.

A person can also not subject to criminal if it has reason or the basis of removal of a criminal which things or conditions that can cause a person to act, which expressly prohibited the criminal code was not punished because the person can't be blamed and his actions no longer an act that is against the law. More specifically, according to the doctrine of the law no person can be punished for the reason forgiving and justification. The reason forgiving (schulduitsluitingsgronden) the subjective and inherent in the person, especially about the mental behavior before or at the time would do. The second reason, namely the fundamental justification (rechtsvaardingingsgronden) that which is objective and attached to a deed or other things outside the soul by the creator.

Not in its criminal maker, for reasons of forgiving (fait a'excuse) although his actions violated the law, which means the deeds that remain are against the law, but because of missing or annulment of the error on the self-maker, then these actions can't be accounted for to him. Different with justification, that there in its criminal maker because of the deeds teersebut lose ssifat against the ruling, although in reality deeds maker has met the elements of the crime, but because of the abolishment of the nature against the law in the act, then the author can not be liable.

\section{CONCLUSION}

Forms of criminal acts in the health services is a criminal offence which is regulated in the criminal code as well as regulated in the Law Practice of Medicine. Health services provided to patients without permit practice doctor is one of the forms of criminal acts that is set in the Legislation of the Republic of Indonesia Number 29 Year 2004 On Medical Practice. Someone who is committing a crime, including criminal acts in the service of health must account for his actions. Its criminal a person must be proven about the crime that he did. Ability is responsible for an element of error, then to prove the existence of a fault element of the last to be proven again. Remember, this is difficult to prove and require quite a long time, then the ability is responsible for considered secretly always there because in general any normal person his innermost feelings, and able to be responsible, unless there are signs showing that the defendant may his soul is not normal.

\section{Acknowledgement: None}

Conflict of Interest: None

Source of Funding: None 
Redyanto Sidi et.al. Criminal liability against a doctor who does not have a license practices in providing health services.

\section{REFERENCES}

1. Abdul Aziz. Tinjauan Kriminologi Mengenai Malpraktik Medik yang dilakukan oleh Perawat. Jurnal Hukum Legal Opinion Edisi 2, Vol. 2.2018.

2. Adami Chazawi. Pelajaran Hukum Pidana Bagian 2. Jakarta: RajaGrafindo Persada. 2016. Adami Chazawi. Pelajaran HukumPidana Bagian I Stelsel Pidana, Tindak Pidana, Teori-

3. Andi Hamzah. Asas-Asas Hukum Pidana. Jakarta: Rineka Cipta. 2014.

4. Bambang Sunggono. Metodologi Penelitian Hukum. Jakarta: Raja Grafindo Persada. 2018.

5. Fachrezi, Faldi Biaggy, and Padmono Wibowo. Upaya Pemenuhan Hak Pelayanan Kesehatan Kepada Narapidana Di Lembaga Pemasyarakatan. Widya Yuridika: Jurnal Hukum 3, no. 2.2020.

6. H. Ishaq. 2020. Hukum Pidana, Jakarta: Raja Grafindo Persada. 2020.

7. Ismu Gunadi dan Jonaedi Efendi. Hukum Pidana, Jakarta: Kencana Prenadamedia Group.2014.

8. Kitab Undang-Undang Hukum Pidana.

9. Mahrus Ali. Asas-Asas Hukum Pidana Korporasi. Jakarta: RajaGrafindo. 2013. Mahrus Ali. Dasar-Dasar Hukum Pidana. Jakarta: Sinar Grafika. 2015.

10. Putusan Mahkamah Agung RI Nomor 2033 K/Pid.Sus/2017.

11. R.Wirjono Prodjodikoro. Asas-Asas Hukum Pidana Di Indonesia. Jakarta: Refika Aditama.2014.
12. Rani Tiyas Budiyanti dan Penggalih Mahardika Herlambang. Perlindungan Hukum Pasien dalam Layanan Kesehatan. Jurnal Hukum Kesehatan Indonesia, Vol. 01, No.1. 2021.

13. Ruslan Renggong. Hukum Pidana Khusus: Memahami Delik-Delik Di Luar KUHP, Jakarta: Prenadamedia Group. 2016.

14. Sitompul, A., \& Sitompul, M. N. (2020, February). The Combination Of Money Laundering Crime With The Origin Of Narkotics Crime To Islamic Law. In Proceeding International Seminar of Islamic Studies (Vol. 1, No. 1, pp. 671-681).

15. Sri Siswati. Etika dan Hukum Kesehatan. Jakarta: Raja Grafindo Persada. 2017.

16. Teori Pemidanaan, dan Batas Berlakunya Hukum Pidana, Jakarta: RajaGrafindo Persada. 2017.

17. Undang-Undang Nomor 29 Tahun 2004 Tentang Praktek Kedokteran. UndangUndang Nomor 23 Tahun 2014 Tentang Keperawatan.

18. Undang-Undang Republik Indonesia Nomor 36 Tahun 2014 Tentang Tenaga Kesehatan. Undang-Undang Republik Indonesia Nomor 36 Tahun 2009 Tentang Kesehatan

How to cite this article: Redyanto Sidi, Kharmaedisyah Putra, Mirza Kesuma et.al. Criminal liability against a doctor who does not have a license practices in providing health services. International Journal of Research and Review. 2021; 8(12): 293-300. DOI: https://doi. org/10.52403/ijrr.20211236 